\title{
TINJAUAN MAQASID SYARI'AH TERHADAP OBLIGASI SYARIAH (SUKUK)
}

\author{
Alvien Septian Haerisma \\ Mahasiswa Pascasarjana Program Doktor \\ Universitas Islam Negeri Sunan Kalijaga Yogyakarta \\ e-mail:alvienseptian@gmail.com
}

\begin{abstract}
One of the instruments offered in the capital market, namely sharia bonds (sukuk). This has become a major attraction for both corporations and governments. With the acquisition of funds through the issuance of sukuk, corporations and the government means that there will be large funds available so as to increase the financing of sharia financial institutions. The need for companies or governments to build the infrastructure and expansion of private companies, this becomes one of the options in realizing alternative funding sources for the company and economic progress nationally. These five needs are aimed at fulfilling the following objectives: (1) Dharuriyah, which is the mandatory requirement to fulfill the needs of the world and the hereafter, (2) Hajj is the need which alleviates the burden of the masyaqah (difficulties) of every human being, (3) Tahsinat, complementary needs. The purpose of this study, trying to outline the benefits of the issuance of sukuk country to the nation and state of Indonesia, also see how the view of maqasid syariah about the benefits of Islamic bonds (sukuk).
\end{abstract}

Keywords: Syariah Bond, Maqasid Syariah, Capital Market Instruments.

\begin{abstract}
Abstrak
Salah satu instrumen yang ditawarkan di pasar modal, yaitu obligasi syariah (sukuk). Hal ini telah menjadi daya tarik utama bagi korporasi maupun pemerintah. Dengan diperolehnya dana melalui penerbitan sukuk, korporasi maupun pemerintah berarti akan tersedia dana yang besar sehingga dapat meningkatkan pembiayaan lembaga keuangan syariah. Kebutuhan perusahaan atau pemerintah guna membangun infrastruktur dan ekspansi perusahaan swasta, hal ini menjadi salah satu pilihan dalam mewujudkan sumber dana alternatif bagi perusahaan dan kemajuan ekonomi secara nasional. Kelima kebutuhan ini bertujuan memenuhi tujuan-tujuan berikut, yaitu: (1) Dharuriyah, yaitu kebutuhan wajib agar terpenuhinya kebutuhan dunia dan akhirat, (2) Hajiyat, yakni kebutuhan yang meringankan beban masyaqah (kesulitan) setiap manusia, (3) Tahsinat, ialah kebutuhan pelengkap. Tujuan dari penelitian ini, mencoba menjabarkan manfaat atas penerbitan sukuk negara bagi bangsa dan negara Indonesia, juga melihat bagaimana pandangan maqasid syariah tentang manfaat obligasi syariah (sukuk).
\end{abstract}

Kata Kunci: Obligasi Syariah, Maqasid Syari'ah, Instrument Pasar Modal. 


\section{PENDAHULUAN}

Dana investasi sangat diperlukan guna pembangunan infrastruktur dan peningkatan keuntungan suatu negara. Istilah investasi bersumber dari dalam dan dari luar negara. Sumber investasi dari luar tidak mungkin selamanya diandalkan untuk pembangunan dalam negeri. Oleh sebab itu, negara harus serius mengelola pendapatan investasi yang bertujuan pembangunan jangka panjang.

Negara memiliki ciri sedang berkembang ketika tingkat tabungan atau investasi yang dihimpun dari masyarakat masih rendah, sehingga dana untuk investasi menjadi tidak mencukupi guna pembangunan dalam negerinya. ${ }^{1}$ Untuk mengatasi kekurangan dana maka negaranegara berkembang membutuhkan pinjaman dari luar negeri. Negara berkembang harus mencari jalan dalam rangka meningkatkan pengerahan tabungan dari masyarakat guna mengusahakan efektivitas pada sektorsektor investasi produktif. Peningkatan pengerahan dana-dana dari masyarakat diperlukan lembaga keuangan baik perbankan maupun non perbankan terus mengupayakan penggalangan dana dari masyarakat tersebut. ${ }^{2}$ Saat ini industri keuangan syariah tumbuh dengan berbagai produknya di tengah-tengah masyarakat. Asuransi syariah dan instrument investasi syariah seperti reksadana maupun obligasi serta diluncurkannya pasar modal syariah telah menyemarakkan dan memberikan pilihan kepada masyarakat untuk berinvestasi di lembaga keuangan syariah dan menerapkan sistem ekonomi syariah dalam aktifitas ekonominya. ${ }^{3}$

Lembaga keuangan turut serta dalam pengerahan dana guna kemajuan

${ }^{1}$ Bruce Lloyd, The Role of Capital Market in Developing Countrie (Spring: The Moorgate and Wall Street, 1976), 46.

${ }^{2}$ Pandji Anoraga dan Piji Pakarti, Pengantar Pasar Modal (Edisi Revisi) (Jakarta: PT. Rineka Cipta, 2006), 1.

${ }^{3}$ Muhammad Amin Suma, Menggali Akar Mengurai Serat Ekonomi dan Keuangan Islam (Jakarta: Kholam Publishing, 2008), 413. perekonomian secara umum. Lembagalembaga keuangan bank dan non bank seperti perbankan, leasing, asuransi, pegadaian, pasar modal dan sebagainya. Pasar modal merupakan lembaga relatif baru yang memperkenalkan diri untuk dimanfaatkan oleh pencari dan penyedia dana.

Pasar modal hakikatnya jaringan tatanan yang memungkinkan pertukaran klaim jangka panjang, penambahan financial assets (dan hutang) pada saat yang sama, memungkinkan investor untuk mengubah dan menyesuaikan portofolio investasi (melalui pasar sekunder). ${ }^{4}$ Pasar modal mempunyai dua fungsi diantaranya fungsi ekonomi dan keuangan. Sudut pandang ekonomi, pasar modal menyediakan fasilitas untuk memindahkan (transfer) dana dari pihak yang memiliki kelebihan dana (investor) kepada pihak yang memerlukan dana (perusahaan penerbit). ${ }^{5}$ Pasar modal menjadi salah satu sumber dana alternatif bagi perusahaan dan kemajuan ekonomi secara nasional.

Pasar modal menawarkan pertukaran atau perdagangan dengan surat-surat berharga seperti saham, sertifikat saham, dan obligasi (sukuk). Kebutuhan terhadap pasar modal Islam disebabkan pasar modal konvensional melaksanakan transaksi perdagangan yang tidak sejalan dengan prinsip Islam. ${ }^{6}$ Pasar modal syariah didasari dengan prinsip-prinsip syariah dapat berkembang lebih besar lagi.

Instrumen yang ditawarkan di pasar modal, yaitu Sukuk (Obligasi Syariah) telah menjadi daya tarik utama di antara bankbank, korporasi dan pemerintah. Sukuk adalah instrumen keuangan beragun aset

\footnotetext{
${ }^{4}$ Bruce Lloyd, The Role of Capital Market in Developing Countrie, 47.

${ }^{5}$ Hulwati, Teori dan Praktiknya dalam Perdagangan Obligasi Syari'ah di Pasar Modal Indonesia dan Malaysia (Jakarta: Ciputat Press Group, 2009), 117.

${ }^{6}$ Hulwati, Teori dan Praktiknya dalam Perdagangan Obligasi Syari'ah di Pasar Modal Indonesia dan Malaysia, 290.
} 
syariah yang diterbitkan oleh lembaga keuangan syariah menurut syariat. Meskipun sering disebut obligasi syariah (sukuk) mirip dengan obligasi konvensional, bahwa sesungguhnya skema sukuk berbeda dengan obligasi konvensional pada umumnya. $^{7}$

Dalam perkembangannya, the Islamic Jurispudence Council (IJC) kemudian mengeluarkan fatwa yang mendukung berkembangnya sukuk. Hal tersebut mendorong Otoritas Moneter Bahrain (BMA - Bahrain Monetary Agency) untuk meluncurkan salam sukuk berjangka waktu 91 hari dengan nilai 25 juta dolar AS pada tahun 2001. Kemudian Malaysia pada tahun yang sama meluncurkan global corporals Sukuk di pasar keuangan Islam internasional. Inilah sukuk global yang pertama kali muncul di pasar internasional. Sebagai contoh, pada tahun 2002 pemerintah Malaysia menerbitkan sukuk dengan nilai 600 juta dolar AS dan terserap habis oleh pasar dengan cepat, bahkan sampai terjadi over subscribe. Begitu pula pada Desember 2004, pemerintah Pakistan menerbitkan sukuk di pasar global dengan nilai 600 juta dolar AS dan langsung terserap habis oleh pasar dan masih banyak contoh lainnya. ${ }^{8}$

Perkembangan di Indonesia, pasca fatwa Dewan Syari'ah Nasional- MUI mengenai haramnya bunga bank lalu tidak lama mengeluarkan fatwa Dewan Syari'ah Nasional-MUI No: 32/DSN- MUI/IX/2002 tersebut memberikan pertimbangan awal bahwa obligasi yang selama ini (konvensional) didefinisikan masih belum sesuai dengan syariah. Karenanya, obligasi yang dibenarkan menurut syariah yaitu obligasi yang berdasarkan prinsip syariah.

\footnotetext{
${ }^{7}$ Mustofa Moh. Hanefah, et al., "Sukuk: Global Issues and Challenges", Journal of Legal, Ethical and Regulatory Issues 16:1 (Juni 2013): 107.

${ }^{8}$ Alvien Septian Haerisma, "Pengantar Obligasi Syariah (Introduction of Islamic Bond (Sukuk)”, Jurnal Al-Amwal 2:1 (Juni 2014): 63-64.
}

Pada awalnya banyak kalangan yang meragukan keabsahan dari obligasi syariah. Dalam perjalannya Indonesia memberikan kepastian hukum atau jalan pada lembaga keuangan syariah membutuhkan penempatan portofolionya pada pasar modal syariah, dengan saham yang halal dalam obligasi syariah. Terutama untuk memenuhi kebutuhan penempatan dana investasi lembaga keuangan syariah yang cenderung over likuiditas. Obligasi syariah (sukuk) merupakan salah satu instrument pasar modal syariah yang diminati oleh investor dari negara lain terutama negara-negara timur tengah, di samping saham syariah dan reksadana syariah.

Dari penjabaran di atas, maka penulis memfokuskan penelitian ini mencoba mengklasifikasikan pertanyaan-pertanyaan diantaranya, yaitu pertama, apa saja manfaat atas penerbitan sukuk negara bagi bangsa dan negara Indonesia? Dan kedua, bagaimana pandangan maqasid syariah tentang manfaat obligasi syariah (Sukuk)? Kebutuhan perusahaan atau pemerintah guna membangun infrastruktur dan ekspansi perusahaan swasta, hal ini menjadi salah satu pilihan dalam mewujudkan sumber dana alternatif bagi perusahaan dan kemajuan ekonomi secara nasional.

\section{LITERATURE REVIEW}

Studi tentang pemikiran maqasid syariah dalam berbagai aspek persoalan kehidupan terutama bidang ekonomi dan diskursus tentang obligasi syariah (sukuk) banyak sekali menyoroti landasan hukum, mekanisme produk dan sebagainya. Diantara penelitian terdahulu sebagai berikut:

Mohamad Sabri Haron, ${ }^{9}$ dalam maqasid syariah tentang harta menjadi wasilah yang penting untuk mencapai

\footnotetext{
${ }^{9}$ Mohamad Sabri Haron, "Wealth Protection in The Context of Maqasid Syariah: Malaysia's Role ini Realizing The Concept of Economic Jihad", Jurnal Hadhari Edisi Khas 2:2 (Desember 2017): 144.
} 
objektif yang paling tinggi yaitu perlindungan terhadap agama (Hifdzu ad-Din). Untuk merealisasikan hal ini, Malaysia telah meletakkan ekonomi sebagai suatu jihad penting untuk mencapai kesejahteraan dalam kehidupan. Malaysia telah memperkenalkan Akta Bank Islam 1983 yang mewujudkan Bank Islam Malaysia Berhad. Dalam masa yang sama sistem perbankan konvensional juga mewujudkan tingkat persaingan dengan sistem perbankan Islam yang kini perkembangannya semakin meluas di bawah Bank Negara Malaysia. Paper ini menjelaskan konsep perlindungan terhadap harta menurut Islam dalam konteks maqasid syariah dan bagaimana peranan Malaysia untuk mengaplikasinya khususnya kepada masyarakat Islam dilanjutkan institusiinstitusi keuangan Islam yang berpotensi di Malaysia menerusi pendekatan jihad ekonomi.

Zariatul Khisan, ${ }^{10}$ Kinerja perbankan syariah tidak hanya terdiri dari aspek kinerja keuangan saja, tetapi juga dilihat dari aspek maqasid syariah. Sehingga pengukuran kinerja bank syariah dari aspek syariah merupakan hal yang sanagat penting diperlukan dalam mengukur kinerja perbankan syariah. Pelaksanaan maqasid syariah merupakan sebuah kewajiban bagi setiap individu atau suatu lembaga keuangan Islam seperti bank syariah, namun sampai pada saat ini belum ada pengukuran kinerja dan laporan maqasid syariah yang dilakukan terhadap bank syariah. Dari hasil penelitian menunjukkan bahwa pengukuran kinerja perbankan syariah dapat ditinjau dari profitabilitas dan maqasid syariah. Pengukuran kinerja maqasid syariah dapat dilakukan dengan pendekatan model IMS. Hasil penelitian ini juga menunjukkan kinerja setiap bank syariah dalam suatu diagram perbandingan sebagai hasil dari

${ }^{10}$ Zariatul Khisan, “Analisis kinerja perbankan syariah ditinjau dari profitabilitas dan maqasid syariah tahun 2010-2013)". (Tesis, Universitas Islam Negeri Malik Ibrahim Malang, 2015), 24. perbandingan kinerja profitabilitasnya dengan pelaksanaan maqasid syariah yang telah dilaksankan atau dilakukan oleh bank syariah.

Desi Trisnawati, ${ }^{11}$ Sukuk adalah salah satu alternatif investasi dan sumber dana pembangunan terutama di bidang infrastruktur karena helebihan dari sukuk sendiri, yaitu (1) yang digunakan sukuk dana dari awal jelas untuk mengembangkan kepastian proyek contoh pembangunan infrastruktur di Indonesia, (2) Risiko sukuk sudah jelas sejak awal proyek, dan (3) Penggunaan dana sukuk harus didisiplinkan karena dana sukuk jelas berkorelasi dengan proyek-proyek tertentu. Pengembangan dari Sukuk di Indonesia perlahan karena aspek regulasi, pajak, operasional dan aspek produk. Faktor-faktor ini Menjadi tantangan bagi pemerintah Indonesia untuk menyelesaikannya Segera agar sukuk menjadi salah satu daya tarik Investasi di Indonesia.

Dalam penelitian terdahulu diatas, hanya berpusat maqasid dan juga obligasi syariah atau sukuk dalam aspek lain, juga gambaran penjelasan permasalahan yang ada. Namun penelitian ini yang menjadi penting untuk membahas pandangan dan tujuan-tujuan maqasid syariah terhadap beberapa manfaat dalam penerbitan obligasi syariah (sukuk) di Indonesia.

\section{METODOLOGI PENELITIAN}

Jenis penelitian yang digunakan adalah penelitian kepustakaan. Penelitian kepustakaan merupakan penelitian yang penemuanya didapatkan dengan mencari data dari berbagai literatur dan referensi yang berhubungan dengan materi pembahasan. ${ }^{12}$ Oleh karena itu, penelitian tentang maqasid syariah tentang obligasi syariah (sukuk) dalam penilitian ini

${ }^{11}$ Desi Trisnawati, "Sukuk sebagai Alternatif Investasi Syari'ah di Indonesia”, Jurnal Kajian Hukum dan Sosial JUSTICIA ISLAMICA 8:1 (Juni 2011): 53.

${ }^{12}$ Moh. Nazir, Metode Penelitian (Bandung: Ghalia Indonesia, 2003), 193. 
menggunakan metode review dokumen dan trend analysis terhadap penerbitan sukuk di Indonesia dan beberapa manfaat di dalamnya.

Pendekatan penelitian yang dilakukan menggunakan pendekatan kualitatif normatif, yaitu sebagaimana cara yang digunakan dalam penelitian hukum yang dilakukan dengan cara meneliti bahan pustaka yang ada. ${ }^{13}$

Teknik pengumpulan data merupakan langkah yang paling strategis dalam penelitian, karena tujuan utama dari penelitian adalah mendapatkan data. ${ }^{14}$ Peneliti melakukan teknik pengumpulan data dengan melakukan penelitian terhadap berbagai literatur yang dilakukan untuk mencari konsep yang ada relevansinya dengan topik pembahasan melalui pengkajian buku-buku, jurnal, majalah, serta pendapat para ahli secara tidak langsung, yang kemudian akan dianalisis secara mendalam. Selain itu, penelitian ini menggunakan teknis analisis deskriptif, yaitu analisis dengan cara memaparkan data yang telah terkumpul dan tersusun secara sistematis. ${ }^{15}$

Sumber diperoleh dari dokumen dan informasi beberapa temuan-temuan di berbagai jurnal dan hasil penelitian sebelumnya. Dokumen tersebut telah melalui tahapan-tahapan analisis dari berbagai keabsahan data atau sumber yang banyak dikaji oleh para peneliti, serta dianalisis dengan fakta bersifat obyektif melihat pasca penerbitan sukuk di Indonesia.

${ }^{13}$ Suerjono Sukanto dan Sri Mamudji, Penelitian Hukum Normatif Suatu Tinjauan Singkat, Cet. 11 (Jakarta: PT. Raja Grafindo Persada, 2009), 13-14.

${ }^{14}$ Sugiyono, Metode Penelitian Kuantitatif, Kualitatif Dan R\&D (Bandung: Alfabeta, 2013), 224.

${ }^{15}$ Jalaludin Rahmat, Metodologi Hukum (Jakarta: Fajar Agung, 1997), 134.

\section{KONSEP DASAR}

\section{Pengertian Obligasi Syariah (Sukuk)}

Sukuk ini bukan merupakan istilah yang baru dalam sejarah Islam. Istilah tersebut sudah dikenal sejak abad pertengahan, dimana umat Islam menggunakannya dalam konteks perdagangan internasional. Sukuk dipergunakan oleh para pedagang pada masa itu sebagai dokumen yang menunjukkan kewajiban finansial yang timbul dari usaha perdagangan dan aktivitas komersial lainnya. ${ }^{16}$

Sukuk merupakan bentuk jamak dari kata sakk (jamak dari sakk) yang disebut sebagai 'obligasi syariah', tetapi terjemahan yang benar dari bahasa Arab kata "Sukukis", (Sertifikat Investasi Islam). Di bawah struktur Sukuk, pemegang Sukuk (investor) masing-masing memegang kepemilikan menguntungkan terbagi dalam "aset Sukuk". 17

Namun demikian, sejumlah penulis barat yang memiliki konsen terhadap sejarah Islam dan bangsa Arab, menyatakan bahwa sakk inilah yang menjadi akar kata "cheque" dalam bahasa latin, yang saat ini telah menjadi sesuatu yang lazim dipergunakan dalam transaksi dunia perbankan kontemporer.

Dalam fatwa DSN No. 32/DSNMUI/IX/2002, "Obligasi Syariah adalah suatu surat berharga jangka panjang berdasarkan prinsip syariah yang dikeluarkan emiten kepada pemegang obligasi syariah yang mewajibkan emiten untuk membayar pendapatan kepada pemegang obligasi syariah berupa bagi hasil/margin/fee, serta membayar kembali dana obligasi pada saat jatuh tempo. ${ }^{18}$

\footnotetext{
${ }^{16}$ Zamir Iqbal dan Abbas Mirakhor (ed), Economic Development and Islamic Finance (Washington DC: The World Bank, 2013), 265.

${ }^{17}$ Tahmoures A. Afshar, "Compare and Contrast Sukuk (Islamic Bonds) with Conventional Bonds, Are they Compatible?" The Journal of Global Business Management 9: 1 (February 2013): 44.

${ }^{18}$ Dewan Syari'ah Nasional-Majelis Ulama Indonesia, Himpunan Fatwa Dewan Syariah Nasional (Jakarta: CV. Gaung Persada, 2006), 197.
} 
Menurut pendapat lain, ${ }^{19}$ obligasi syariah adalah suatu kontrak perjanjian tertulis yang bersifat jangka panjang untuk membayar kembali pada waktu tertentu seluruh kewajiban yang timbul akibat pembiayaan untuk kegiatan tertentu menurut syarat dan ketentuan tertentu serta membayar sejumlah manfaat secara periodik menurut akad.

\section{Perbedaan Obligasi Syariah (Sukuk) dan Obligasi Konvensional}

Perbedaan antara obligasi syariah dan obligasi konvensional dapat dilihat dari beberapa sisi. Pertama, dari emiten. Emiten yang akan menerbitkan obligasi syariah harus berasal dari emiten yang aktivitas bisnisnya tidak bertentangan dengan ketentuan syariah. Kedua, dari sisi peringkat investment guide. Obligasi syariah memiliki fundamental usaha yang kuat, baik di mata masyarakat. Ketiga, dari sisi struktur obligasi. Obligasi syariah menerbitkan obligasi mudharabah (obligasi berpendapatan tetap) dan obligasi ijarah ${ }^{20}$.

Perbedaan paling mendasar antara obligasi syariah dan obligasi konvensional yang didefinisikan sebagai instrumen utang jangka panjang yang diterbitkan oleh perusahaan dan pemerintah terletak pada: a) obligasi konvensional sebagai surat utang, namu sukuk merupakan surat investasi; b) penetapan bunga yang besarnya sudah ditentukan diawal transaksi jual-beli. Sedangkan pada obligasi syariah saat perjanjian jual beli belum ditentukan besarnya bunga. Yang ditentukan adalah berapa proporsi pembagian hasil apabila mendapatkan keuntungan di masa yang akan datang. Memberikan gambaran dari perbedaan antara sukuk dan obligasi, tergambar skema dibawah ini:

\footnotetext{
${ }^{19}$ Sofiniyah Ghufron (ed.), Briefcase Book Edukasi Profesional Syariah: Konsep Dasar Obligasi Syariah (Jakarta: Renaisan, 2005), 17.

${ }^{20}$ Sofiniyah Ghufron (ed.), Briefcase Book Edukasi Profesional Syariah: Konsep Dasar Obligasi Syariah, 14.
}

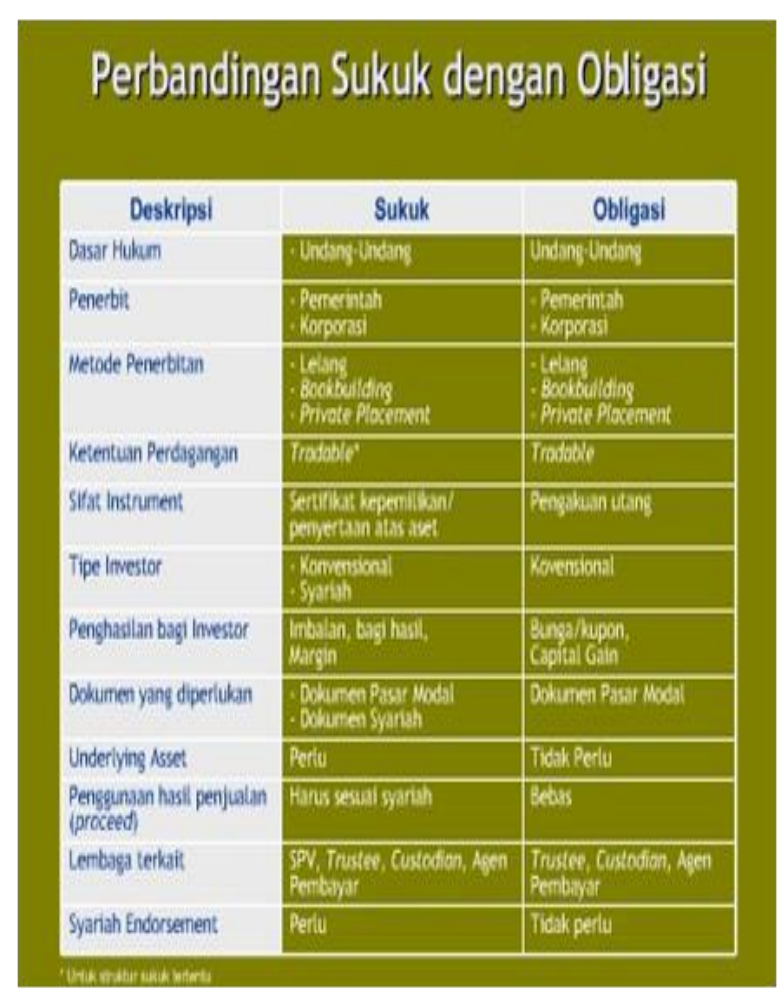

Sumber: Departemen Keuangan (2010)

\section{Landasan Hukum Obligasi Syariah (Sukuk)}

Mengingat sesuai fatwa Dewan Syari'ah Nasional-MUI dalam menetapkan bolehnya obligasi syariah adalah:

a. Firman Allah SWT, QS. Al-Maidah (5): 1 yang berbunyi:

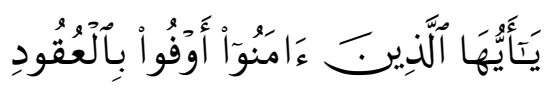

"Hai orang-orang yang beriman, penuhilah aqad-aqad itu...". 21

${ }^{21}$ Ibnu Abi Hatim mengatakan dari az-Zuhri, ia berkata: "Apabila Allah berfirman: "Hai orangorang yang beriman," kerjakanlah oleh kalian, maka Nabi saw termasuk dari mereka." Allah berfirman: "Penuhilah aqad-aqad itu." Ibnu 'Abbas Mujahid dan beberapa ulama lainnya mengatakan: "Yang dimaksud dengan aqad adalah perjanjian." Dan Ibnu Jarir juga menceritakan adanya ijma' tentang hal itu. Ia mengatakan "Perjanjian-perjanjian adalah apa yang mereka sepakati, mencakup: janji prasetia hamba kepada Allah dan perjanjian yang dibuat oleh manusia dalam pergaulan sesamanya. Ali bin Abi Thalhah mengatakan dari Ibnu 'Abbas (ia berkata): bahwa perjanjian tersebut adalah segala yang dihalalkan dan diharamkan Allah, yang difardhukan, dan apa yang ditetapkan Allah di dalam al-Qur'an secara keseluruhan, maka janganlah kalian 

34:

Ayat lain dalam QS. Al-Isra' (17):

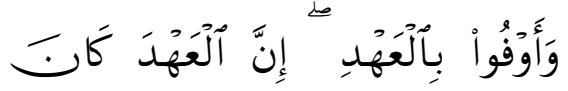

$$
\begin{aligned}
& \text { مَنَعُولاًا } \\
& \text { “.....penuhilah janji; } \\
& \text { Sesungguhnya janji itu pasti } \\
& \text { diminta pertanggungan } \\
& \text { jawabnya". } 22
\end{aligned}
$$

b. Hadist Nabi riwayat Imam at-Tirmidzi dari "Amr bin 'Auf al-Muzani, Nabi saw. Bersabda: ${ }^{23}$

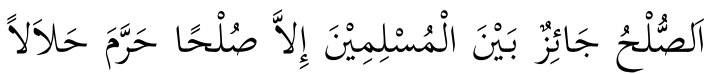

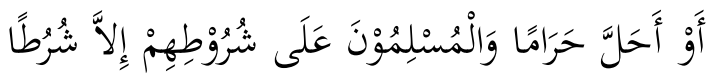

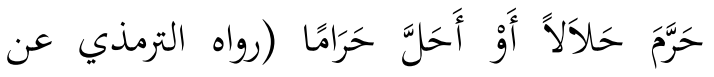

$$
\begin{aligned}
& \text { عمرو بن عوف) }
\end{aligned}
$$

Hadis Nabi saw. riwayat Imam Ibu Majah, al-Daruquthni, dan yang lain, dari

mengkhianati dan melanggarnya." Lihat Abdullah bin Muhammad bin Abdurahman bin Ishaq AlSheikh, Tafsir Ibnu Katsir, Juz 6 (Bogor: Pustaka Imam Asy-Syafi'i, 2004), 2-3.

${ }^{22}$ Dan firman-Nya: "Dan penuhilah janji." Yaitu perjanjian yang kalian perbuat kepada manusia dan ikatan kerja yang kalian pekerjakan mereka dengan ikatan kerja tersebut, karena sesungguhnya kedua hal itu akan dimintai pertanggungjawab dari pelakunya, "Sesungguhnya janji itu pasti dimintai pertanggungjawabnya." Lihat Abdullah Bin Muhammad Bin Abdurahman Bin Ishaq Al-Sheikh, Tafsir Ibnu, Katsir Juz 15 (Bogor: Pustaka Imam Asy-Syafi'i, 2004), 163-164.

${ }^{23}$ Dewan Syari'ah Nasional-Majelis Ulama Indonesia, Himpunan Fatwa Dewan Syariah Nasional, 195.
Abu Sa'id al-Khudri, Nabi saw. bersabda:

$$
\text { لاضرر ولاضرار (رواه ابن ماجه وادارقطنى }
$$

$$
\text { وغيرهما }
$$

"Tidak boleh membahayakan (merugikan) diri sendiri maupun orang lain"

\section{c. Kaidah Fiqh :}

Keberadaan Obligasi Syariah (sukuk) dibolehkan karena mengacu kaidah fiqh, menawarkan kebolehan atau mubah dalam kegiatan muamalah (hubungan manusia dengan manusia yang lainnya). Kaidah tersebut ialah: ${ }^{24}$

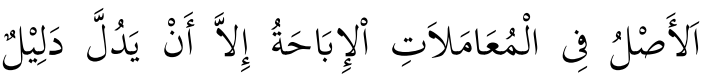

$$
\begin{aligned}
& \text { عَلَى تَخِْيمِهِا. }
\end{aligned}
$$

"Pada dasarnya, semua bentuk muamalah boleh dilakukan kecuali ada dalil yang mengharamkannya."

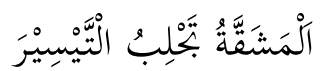

"Kesulitan dapat menarik kemudahan"

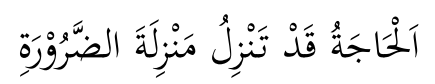

"Keperluan dapat menduduki posisi darurat"

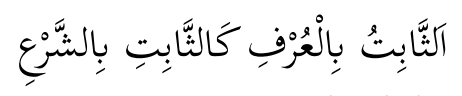

"Sesuatu yang berlaku berdasarkan adat kebiasaan sama dengan sesuatu yang berlaku berdasarkan syara' (selama tidak bertentangan dengan syari'at)"

\section{Akad-Akad dalam Obligasi Syariah (Sukuk)}

Sukuk dapat terstruktur bersama teknik yang berbeda. Sementara obligasi konvensional adalah janji untuk membayar pinjaman, Sukuk merupakan kepemilikan parsial

${ }^{24}$ Dewan Syari'ah Nasional-Majelis Ulama Indonesia, Himpunan Fatwa Dewan Syariah Nasional, 196-197. 
dalam utang (Murabahah sukuk), aset (AlIjarah sukuk), proyek (Al-Istisna'a sukuk), bisnis (Al-Musyarakah sukuk) atau investasi (Al-Mudharabah sukuk). Baru-baru ini, ada satu jenis sukuk yang memperkenalkan sukuk campuran (Hybrid sukuk). ${ }^{25}$

Sebagai bentuk pendanaan (financing) dan sekaligus investasi memungkinkan beberapa bentuk atau struktur sesuai dengan syariah. Salah satunya adalah menghindarkan segala jenis transaksi dari unsur riba. Akad yang dapat digunakan dalam penerbitan obligasi syariah (sukuk) di Indonesia antara lain : (1) Ijarah; (2) Mudharabah; (3) Musyarakah; (4) Istisna; (5) Murabahah; dan (6) Hybrid Sukuk. ${ }^{26}$

a. Sukuk Ijarah, hal ini dibagi menjadi Perjanjian Pembelian, perjanjian sewa, perjanjian servis dan pembelian usaha. Ini berdasarkan membiarkan hak properti untuk manfaat lain berdasarkan harga yang disepakati. ${ }^{27}$

b. Sukuk Mudharabah, hal ini dibagi menjadi kesepakatan Mudharabah dan pembelian usaha. Ini adalah perjanjian kerjasama antara dua pihak investor dan manajer modal. Mudharabah sukuk adalah sukuk investasi yang mewakili kepemilikan umum unit dengan nilai yang sama dalam ekuitas Mudharabah. ${ }^{28}$

c. Sukuk Musyarakah: Hal ini dibagi menjadi kesepakatan Musyarakah, perjanjian manajemen, pembelian usaha. Itu melibatkan kerjasama dua pihak untuk menggabungkan modal untuk motivasi.

d. Sukuk Istisna: Perjanjian jual beli untuk membiayai item proyek. Istisna'a

\footnotetext{
${ }^{25}$ Mohamad Zaid Moh Zin, et.al., "The Effectiveness of Sukuk in Islamic Finance Market", Australian Journal of Legal, Ethical and Regulatory Issues 12:5 (Oktober 2011): 473.

${ }^{26}$ Ismail Nawawi, Fiqih Muamalah; Klasik dan Kontemporer (Bogor: Penerbit Ghalia Indonesia, 2012), 138.

${ }^{27}$ Sofiniyah Ghufron (ed.), Briefcase Book Edukasi Profesional Syariah: Konsep Dasar Obligasi Syariah, 32-34.

${ }^{28}$ Alvien Septian Haerisma, "Pengantar Obligasi Syariah (Introduction of Islamic Bond (Sukuk)", 73-76.
}

sukuk adalah sertifikat yang membawa nilai yang sama dan dikeluarkan untuk memobilisasi dana yang diperlukan untuk produksi produk barang yang akan dimiliki oleh pemegang sertifikat. ${ }^{29}$

e. Sukuk Murabahah: Dalam kasus Murabahah sukuk, penerbit sertifikat adalah penjual komoditi Murabahah tersebut pelanggan adalah pembeli komoditi itu, dan mereka berhak untuk harga jual akhir setelah re-penjualan komoditi.

f. Hybrid Sukuk: Struktur yang inovatif. Berdasarkan berbagai tuntutan investor, semacam lebih beragam dari sukuk hybrid atau campuran sukuk muncul di pasar. Aset dapat terdiri dari istisna'a murabahah, serta ijarah. Islamic Development Bank mengeluarkan Sukuk Hybrid pertama untuk US \$ 400 juta. Aset terdiri $66 \%$ al-Ijarah sukuk, $31 \%$ Murabahah dan 3\% al-Istisna'a sukuk.The struktur hybrid sukuk merupakan potensi struktur baru dan manfaat bagi investor. ${ }^{30}$

\section{Pengertian dan Tujuan Maqasid Syariah}

Secara hierarkis maqasid syariah memilik persamaan tujuan yakni kulliyatu alkhomsah (lima hajat manusia) yang harus dipenuhi dan terlindungi adalah: (a) Perlindungan terhadap Agama (Hifdzu ad-Din); (b) Perlindungan terhadap Jiwa (Hifdzu an-nafs); (c) Perlindungan terhadap Akal (Hifdzu al-Aql); (d) Perlindungan terhadap Keturunan (Hifdzu an-Nasl); (e) Perlindungan terhadap Harta (Hifdzu al-Mal). Setelah mengetahui alat ukur yang digunakan yaitu tingkatan maqasid syariah yang terbingkai dalam ad-dharuriyah al-khams. Maka metode yang digunakan untuk menganalisis data penelitian ini yaitu dengan menggunakan analisis domain. ${ }^{31}$

\footnotetext{
${ }^{29}$ Mohamad Zaid Moh. Zin, et al., "The Effectiveness of Sukuk in Islamic Finance Market", 473-474.

${ }^{30}$ Mohamad Zaid Moh. Zin, et.al., "The Effectiveness of Sukuk in Islamic Finance Market", 473-474.

${ }^{31}$ Maftukhatusolikhah, "Mempertimbangkan Tingkat Maqasid Asy-Syari'ah dalam Penentuan
} 
Kelima kebutuhan ini bertujuan memenuhi tujuan-tujuan berikut, ${ }^{32}$ yaitu: (1) Dharuriyah, yaitu kebutuhan wajib agar terpenuhinya kebutuhan dunia dan akhirat, (2) Hajiyat, yakni kebutuhan yang meringankan beban masyaqah (kesulitan) setiap manusia, (3) Tahsinat, ialah kebutuhan pelengkap.

\section{PEMBAHASAN DAN DISKUSI}

Bentuk Obligasi Syariah (Sukuk) Negara di Indonesia

Di Indonesia payung hukum yang menjadi landasan penerbitan obligasi/sukuk, adalah UU No. 19 tahun 2008 tentang Surat Berharga Syariah. Tersirat pada UU No. 19 Tahun 2008 Tentang Surat Berharga Syariah Negara (SBSN) menjelaskan bahwa Surat Berharga Syariah Negara selanjutnya disingkat SBSN, atau dapat disebut Sukuk Negara, adalah surat berharga negara yang diterbitkan berdasarkan prinsip syariah, sebagai bukti atas bagian penyertaan terhadap Aset SBSN, baik dalam mata uang rupiah maupun valuta asing. ${ }^{33}$

Menurut perkembangan, sesunggunya telah mulai proses panjang, yaitu sejak tahun 2003 ketika Dewan Syariah Nasional Majelis Ulama Indonesia (DSN-MUI) menyuarakan penerbitan sukuk untuk menangkap peluang investasi sekaligus perkembangan perekonomian syariah di Indonesia. DSN-MUI juga telah melontarkan ide amandemen UndangUndang Nomor 2002 tentang Surat Utang Negara tetapi ide ini juga kandas. Pada tahun 2005, DSN-MUI kembali mengajukan usulan agar pemerintah segera mengeluarkan Undang-Undang tentang Surat Berharga Syariah, usaha tersebut telah berhasil dengan diterbitkannya UndangUndang No. 19 tahun 2008 tersebut.

Anggaran Belanja Pemerintah", Jurnal I-Finance 1:1 (Juli 2015): 42.

${ }^{32}$ Oni Sahroni dan Adiwarman A. Karim, Maqasid Bisnis dan Keuangan Islam: Sistesis Fiqh dan Ekonomi (Jakarta: Rajawali Press, 2015): 50.

${ }^{33}$ Pasal 1 UU No. 19 Tahun 2008 tentang Surat Berharga Syariah Negara (SBSN).
Dari segi manfaat, penerbitan sukuk negara ternyata memiliki banyak manfaat bagi bangsa dan negara Indonesia. Manfaatmanfaat tersebut antara lain:

1. Memperluas alternatif sumber pembiayaan APBN, persoalan mendasar ketika terbatasnya dana pemerintah dari APBN untuk menggerakkan pembangunan sektor ekonomi, maka diperlukan instrumen pembiayaan lainnya seperti surat berharga syariah Negara (SBSN) atau sukuk negara ini.

2. Membiayai pembangunan proyek infrastruktur, pembiayaan proyek melalui penerbitan SBSN merupakan salah satu tahapan yang diharapkan dapat menjadi pendorong tercapainya tujuan pembangunan nasional.

3. Memperkuat dan meningkatkan peran sistem keuangan berbasis di dalam negeri, sukuk ini diharapkan industri keuangan syariah dapat turut berpartisipasi dan berperan aktif dalam pembiayaan APBN, baik langsung maupun tidak langsung.

4. Memperluas dan mendiversifikasi basis investor, sistem flektibilitas dapat semakin memperluas basis investor surat berharga negara karena tidak hanya bisa menjangkau investor syariah, namun juga investor konvensional.

5. Mengembangkan alternatif instrumen investasi, sukuk tersebut diharapkan dapat menjadi alternatif instrumen investasi syariah di pasar modal dan pasar uang, selain investasi di saham, obligasi dan reksadana. $^{34}$

6. Mendorong Pertumbuhan dan Pengembangan Pasar Keuangan Syariah di dalam negeri seperti mengembangkan alternatif

${ }^{34}$ Yudi Suharso, "8 Manfaat Sukuk Negara", dalam http://akucintakeuangansyariah.com. Diakses pada tanggal 8 Maret 2017. 
instrument portofolio investasi lembaga keuangan syariah antara lain perbankan syariah, reksadana syariah dan asuransi syariah.

7. Menciptakan benchmark di pasar keuangan syariah, ini diharapkan dapat menjadi benchmark acuan bagi penerbitan sukuk lainnya, baik oleh korporasi maupun entitas lainnya, seperti pemerintah daerah.

8. Mengoptimalkan pemanfaatan Barang Milik Negara (BMN) dan mendorong tertib administrasi pengelolaan barang milik negara BMN, serta mampu mengatur keuangan perusahaan dengan memberikan likuiditas yang lebih baik. $^{35}$

\section{Pandangan Maqasid Syariah tentang Obligasi Syariah (Sukuk)}

Jual beli sukuk perusahaan itu hukumnya boleh baik secara tunai ataupun tidak tunai (untuk sukuk-sukuk yang boleh diperjualbelikan secara tidak tunai) dengan syarat kegiatan perusahaan baik investasi atau sharf tidak bertentangan dengan syariah. ${ }^{36}$ Hal ini berdasarkan dalil bahwa sukuk tersebut adalah milik syarik (pelaku syirkah) dan ia berhak melakukan apa saja terhadap sukuk yang menjadi miliknya, terlebih lagi setiap syarik sudah mengizinkan kepada syarik yang lain untuk menggunakan porsi sukuknya. Izin tersebut dibuktikan dengan persetujuannya atas ketentuan perusahaan. ${ }^{37}$ bahwa:

$$
\text { Ibnu Quddamah, }{ }^{38} \text { menjelaskan }
$$

\footnotetext{
${ }^{35}$ Desi Trisnawati, "Sukuk sebagai Alternatif Investasi Syari'ah di Indonesia”, 57-58.

${ }^{36}$ A1-Ma'sayir asy-Syar'iyah, Hai'atu alMuhasabah wa al-Muraja'ah li alMuassasat al-Maliyah al-Islamiyah (Bahrain: t.t, 2010), 293.

${ }^{37}$ Oni Sahroni dan Adiwarman A. Karim, Maqasid Bisnis dan Keuangan Islam: Sistesis Fiqh dan Ekonomi, 183.

${ }^{38}$ Ibnu Quddamah, Al-Mughni, Cet. I (Beirut: Dar al-Fikr, 1985), 173.
}

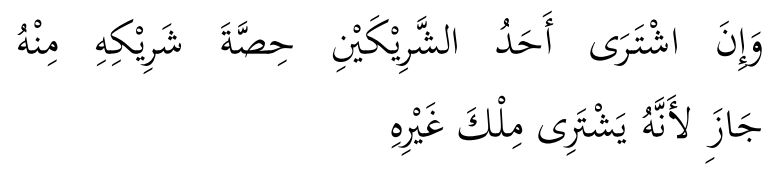

"Jika salah seorang dari dua orang berserikat membeli porsi mitra serikatnya, hukumnya boleh, karena ia membeli milik pihak lain".

Setiap barang/komoditas yang diperjualbelikan harus sesuatu yang bernilai (mal mutaqawwam) menurut tradisi pasar dan perundang-undangan yang berlaku. Begitu pula dengan sukuk, sebagai surat berharga harus menjadi bukti kepemilikan atas aset tertentu yang halal sehingga bisa dimiliki dan diperjualbelikan.

Oleh karena itu, standar syariah AAOIFI memberikan syarat-syarat (dhowabith), ${ }^{39}$ sebagai berikut:

a. Sukuk boleh

dipasarkan/diperjualbelikan jika berbentuk porsi kepemilikan aset baik barang, manfaat dan jasa setelah ditutupnya penawaran umum dan usaha investasinya telah berjalan.

Jika usahanya belum dimulai, maka jual beli sukuk harus mengkuti kaidah sharf. Dan jika sudah ditashfiyah sedangkan aset masih berbentuk utang atau menjual aset yang menjadi underlying asetnya dijual dengan harga tidak tunai itu harus mengikuti kaidah tentang utang piutang.

b. Sukuk boleh dipasarkan dengan cara-cara yang tidak bertentangan dengan syara' seperti al-qaid $f i$ sijillat, sarana elektronik dan munawalah.

c. Sukuk ijarah aset (yang disewakan atau yang dijanjikan untuk disewa) itu boleh dipasarkan sejak sukuk tersebut diterbitkan. Sukuk aset yang disewakan boleh dikembalikan dari penerbit sukuk sebelum waktunya

${ }^{39}$ Oni Sahroni dan Adiwarman A. Karim, Maqasid Bisnis dan Keuangan Islam: Sistesis Fiqh dan Ekonomi, 183-184. 
dengan menggunakan harga pasar atau harga yang disepakati pemegang sukuk dan penerbitnya.

d. Sukuk jasa boleh dipasarkan sebelum aset tersebut disewakan. Jika tidak disewakan ulang, maka sukuk pada upah. Pada saat itu sukuk menjadi utang penyewa kedua. Oleh karena itu, jual beli sukuk mengikuti kaidah transaksi utang.

e. Penerbit boleh mengambil kembali sukuk jasa dari pemilik sukuk setelah harga jasa diterima perusahaan emiten baik dengan harga pasar atau harga yang disepakati kedua belah pihak pada waktu pengembalian, dengan syarat jasa diterima perusahaan emiten baik dengan harga pasar atau harga yang disepakati kedua belah pihak pada waktu pengembalian dengan syarat harga penawaran itu tidak boleh tempo.

f. Sukuk manfaat barang (maushuf $f i$ dzimmah) tidak boleh dipasarkan sebelum barangnya bisa dimanfaatkan kecuali mengikuti kaidah transaksi jual beli utang. Jika barangnya sudah tertentu, maka boleh dipasarkan.

g. Sukuk murabahah tidak boleh dipasarkan jika barang itu telah dijual ke pembeli. Tetapi jika barang tersebut sudah dibeli tetapi belum dijual kepada pembeli, maka itu boleh dipasarkan.

i. Sukuk mudharabah, sukuk musyarakakah, sukuk wakalah bil istitsmar bisa dipasarkan setelah ditutup penawaran umum dan usahanya telah dimulai.

j. Sukuk tidak boleh dijadikan objek salam karena itu berarti menjadikan sukuk utang yang harus dibayarkan. Dan itu tidak dibolehkan karena penjual sukuk menjual sukuk yang belum dimilikinya.
Skema

Obligasi Syariah (sukuk) berdasarkan manfaat dalam Maqasid Syari'ah

\begin{tabular}{|c|c|c|}
\hline No. & $\begin{array}{l}\text { Maqasid } \\
\text { Syari'ah }\end{array}$ & $\begin{array}{c}\text { Obligasi Syariah } \\
\text { (sukuk) berdasarkan } \\
\text { manfaat }\end{array}$ \\
\hline \multirow[t]{2}{*}{1.} & \multirow[t]{2}{*}{$\begin{array}{l}\text { Agama } \\
\text { (Hifdzu } \\
\text { ad-Din) }\end{array}$} & $\begin{array}{c}\text { Menciptakan } \\
\text { benchmark instrumen } \\
\text { keuangan syariah } \\
\text { (mensyiarkan nilai - } \\
\text { nilai Islam dalam } \\
\text { produk keuangan) }\end{array}$ \\
\hline & & $\begin{array}{c}\text { Mengembangkan } \\
\text { alternatif instrumen } \\
\text { investasi } \\
\text { (salah satu model } \\
\text { investasi berbasis } \\
\text { syariah yang akan } \\
\text { mengeliat sehingga } \\
\text { umat Islam akan } \\
\text { mampu secara finasial } \\
\text { dan tidak akan } \\
\text { tergoyahkan rasa } \\
\text { keimanannya kepada } \\
\text { Tuhannya) }\end{array}$ \\
\hline \multirow[t]{2}{*}{2.} & \multirow[t]{2}{*}{$\begin{array}{c}\text { Jiwa } \\
\text { (Hifdzu } \\
\text { an-nafs) }\end{array}$} & $\begin{array}{c}\text { Membiayai } \\
\text { pembangunan proyek } \\
\text { infrastruktur } \\
\text { (pembangunan pabrik } \\
\text { atau perusahaan } \\
\text { BUMN/BUMD guna } \\
\text { menampung tenaga } \\
\text { kerja usia produktif) }\end{array}$ \\
\hline & & $\begin{array}{c}\text { Mendorong } \\
\text { Pertumbuhan dan } \\
\text { Pengembangan Pasar } \\
\text { Keuangan Syariah di } \\
\text { Indonesia } \\
\text { (para pekerja yang } \\
\text { professional dapat } \\
\text { mengisi kesempatan } \\
\text { dalam industri } \\
\text { keuangan syariah) }\end{array}$ \\
\hline 3. & $\begin{array}{c}\text { Akal } \\
\text { (Hifdzu }\end{array}$ & $\begin{array}{c}\text { Membiayai } \\
\text { pembangunan proyek }\end{array}$ \\
\hline
\end{tabular}




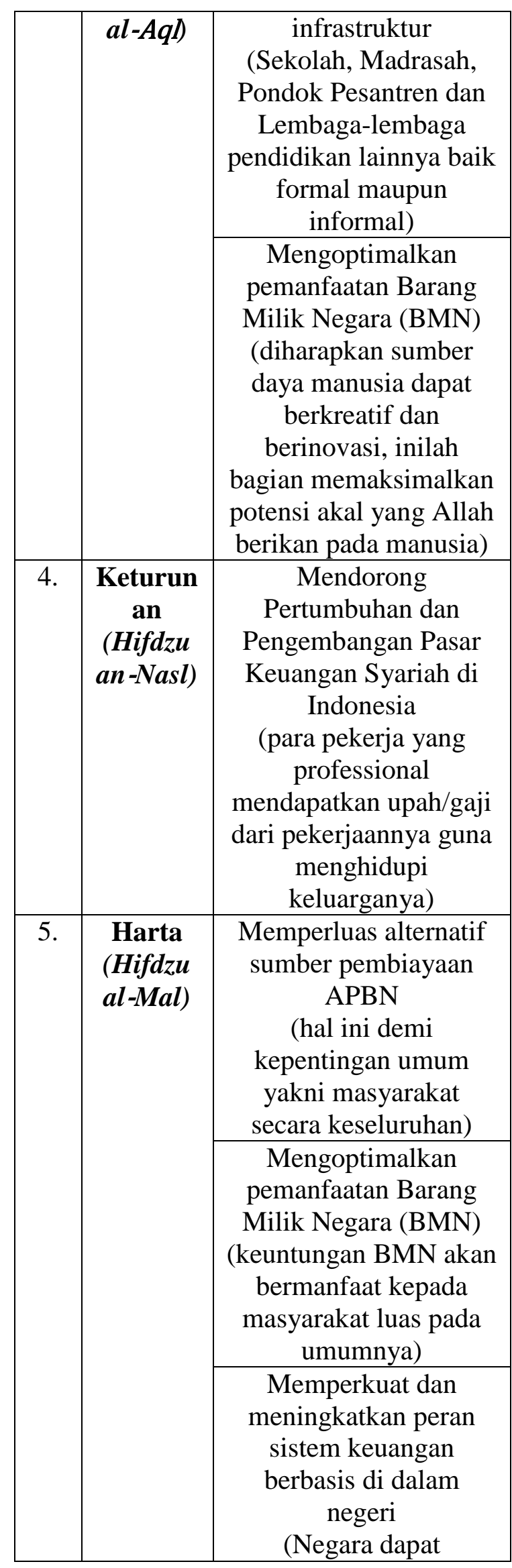

\begin{tabular}{|c|c|}
\hline \multirow{1}{|c|}{} & $\begin{array}{c}\text { mengelola dengan baik } \\
\text { dan hasilnyapun akan } \\
\text { dirasakan oleh } \\
\text { masyarakat itu sendiri) }\end{array}$ \\
\cline { 2 - 2 } & $\begin{array}{c}\text { Memperluas dan } \\
\text { mendiversifikasi basis } \\
\text { investor }\end{array}$ \\
& $\begin{array}{c}\text { Mengembangkan } \\
\text { alternatif instrumen } \\
\text { investasi } \\
\text { (sebagai salah satu } \\
\text { model investasi } \\
\text { berbasis syariah guna } \\
\text { mengakomodir } \\
\text { kepentingan umat Islam } \\
\text { umumnya masyarakat } \\
\text { luas) }\end{array}$ \\
\hline
\end{tabular}

Alasan yang melatarbelakangi menciptakan benchmark instrumen keuangan syariah termasuk dalam kategori agama, karena sesuai dengan apa yang telah disampaikan mengenai hak pokok dalam pemeliharaan agama atau sesuai syariah karena instrument keuangan yakni obligasi syariah (sukuk) memiliki dan menerapkan nilai-nilai kesyari'ahan terdapat poin termasuk melaksanakan da'wah demi kemajuan secara umum nilai-nilai Islam.

Dalam perlindungan agama (Hifdzu ad-Din), yang kaitannya dari manfaat sukuk yaitu terdapat: menciptakan benchmark instrumen keuangan syariah (mensyiarkan nilai - nilai Islam dalam produk keuangan) dan mengembangkan alternatif instrumen investasi (salah satu model investasi berbasis syariah yang akan mengeliat sehingga umat Islam akan mampu secara finasial dan tidak akan tergoyahkan rasa keimanannya kepada Tuhannya).

Aspek pemeliharaan jiwa (Hifdzu an-nafs), dalam manfaat sukuk diantaranya: membiayai pembangunan proyek infrastruktur (pembangunan pabrik atau perusahaan BUMN/BUMD guna menampung tenaga kerja usia produktif) dan mendorong pertumbuhan dan pengembangan pasar keuangan syariah di 
Indonesia (para pekerja yang professional dapat mengisi kesempatan dalam industri keuangan syariah).

Lingkup perlindungan akal (Hifdzu al-Aql), yang kaitannya dari manfaat sukuk yaitu terdapat: membiayai pembangunan proyek infrastruktur (Sekolah, Madrasah, Pondok Pesantren dan Lembaga-lembaga pendidikan lainnya baik formal maupun informal) dan mengoptimalkan pemanfaatan Barang Milik Negara (BMN) (diharapkan sumber daya manusia dapat berkreatif dan berinovasi, inilah bagian memaksimalkan potensi akal yang Allah berikan pada manusia).

Kategori pemeliharaan keturunan (Hifdzu an-nasl), dalam manfaat sukuk diantaranya: mendorong pertumbuhan dan pengembangan pasar keuangan syariah di Indonesia (para pekerja yang profession al mendapatkan upah/gaji dari pekerjaannya guna menghidupi keluarganya).

Akhirnya, dalam pemeliharaan harta (Hifdzu al-Mal), terdapat manfaat sukuk diantaranya: memperluas alternatif sumber pembiayaan APBN, mengoptimalkan pemanfaatan Barang Milik Negara (BMN), memperkuat dan meningkatkan peran sistem keuangan berbasis di dalam negeri, memperluas dan mendiversifikasi basis investor, mengembangkan alternatif instrumen investasi dalam penempatan urutan terakhir dari pemeliharaan lima kebutuhan pokok dalam hidup manusia. Harta juga hanya dijadikan sebagai alat pemenuhan kebutuhan, sehingga tidak juga dapat dikesampingan dalam perekonomian. Fungsi pelayanan umum, karena mencakup seluruh bidang baik yang ditangani kementerian atau lembaga maupun non kementerian atau lembaga, maka tidak akan menjadi objek analisis.

\section{KESIMPULAN}

Dalam fatwa DSN No. 32/DSNMUI/IX/2002, "Obligasi Syariah adalah suatu surat berharga jangka panjang berdasarkan prinsip syariah yang dikeluarkan emiten kepada pemegang obligasi syariah yang mewajibkan emiten untuk membayar pendapatan kepada pemegang obligasi syariah berupa bagi hasil/margin/fee, serta membayar kembali dana obligasi pada saat jatuh tempo.

Secara hierarkis maqasid syariah memilik persamaan tujuan yakni kulliyatu al-khomsah (lima hajat manusia) yang harus dipenuhi dan terlindungi adalah: (a) Perlindungan terhadap Agama (Hifdzu ad-Din); (b) Perlindungan terhadap Jiwa (Hifdzu an-nafs); (c) Perlindungan terhadap Akal (Hifdzu al-Aql); (d) Perlindungan terhadap Keturunan (Hifdzu an-Nasl); (e) Perlindungan terhadap Harta (Hifdzu al-Mal). Setelah mengetahui alat ukur yang digunakan yaitu tingkatan maqasid syariah yang terbingkai dalam ad-dharuriyah al-khams. Maka metode yang digunakan untuk menganalisis data penelitian ini yaitu dengan menggunakan analisis domain.

Dalam perlindungan agama (Hifdzu ad-Din), terdapat: menciptakan benchmark instrumen keuangan syariah dan mengembangkan alternatif instrumen investasi. Aspek pemeliharaan jiwa (Hifdzu an-nafs), diantaranya: membiayai pembangunan proyek infrastruktur dan mendorong pertumbuhan dan pengembangan pasar keuangan syariah di Indonesia. Lingkup perlindungan akal (Hifdzu al-Aql), terdapat: membiayai pembangunan proyek infrastruktur dan mengoptimalkan pemanfaatan Barang Milik Negara (BMN). Kategori pemeliharaan keturunan (Hifdzu an-nasl), diantaranya: mendorong pertumbuhan dan pengembangan pasar keuangan syariah di Indonesia. Akhirnya, dalam pemeliharaan harta (Hifdzu al-Mal), diantaranya: memperluas alternatif sumber pembiayaan APBN, mengoptimalkan pemanfaatan Barang Milik Negara (BMN), memperkuat dan meningkatkan peran sistem keuangan berbasis di dalam negeri, memperluas dan mendiversifikasi basis investor, mengembangkan alternatif instrumen investasi dalam penempatan urutan terakhir 
dari pemeliharaan lima kebutuhan pokok dalam hidup manusia.

\section{DAFTAR PUSTAKA}

A1-Ma'asyir asy-Syar'iyah. Hai'atu alMuhasabah wa al-Muraja'ah li alMuassasat al-Maliyah al-Islamiyah. Bahrain: t.t, 2010.

Afshar, Tahmoures A. "Compare and Contrast Sukuk (Islamic Bonds) with Conventional Bonds, Are they Compatible?". The Journal of Global Business Management 9:1 (February 2013).

Al-Sheikh, Abdullah bin Muhammad bin Abdurahman bin Ishaq. Tafsir Ibnu Katsir, Juz 6. Bogor: Pustaka Imam Asy-Syafi'i, 2004.

Al-Sheikh, Abdullah bin Muhammad bin Abdurahman bin Ishaq. Tafsir Ibnu Katsir, Juz 15. Bogor: Pustaka Imam Asy-Syafi'i, 2004.

Anoraga, Pandji dan Piji Pakarti. Pengantar Pasar Modal (Edisi Revisi). Jakarta: PT. Rineka Cipta, 2006.

Dewan Syari'ah Nasional-Majelis Ulama Indonesia, Himpunan Fatwa Dewan Syariah Nasional. Jakarta: CV. Gaung Persada, 2006.

Ghufron, Sofiniyah (ed.). Briefcase Book Edukasi Profesional Syariah: Konsep Dasar Obligasi Syariah. Jakarta: Renaisan, 2005.

Haerisma, Alvien Septian. "Pengantar Obligasi Syariah (Introduction of Islamic Bond (Sukuk)". Jurnal AlAmwal 2:1 (Juni 2014).

Hanefah, Mustofa Moh., et al. "Sukuk: Global Issues and Challenges". Journal of Legal, Ethical and Regulatory Issues 16:1 (Juni 2013).

Haron, Mohamad Sabri. "Wealth Protection in The Context of Maqasid Syariah: Malaysia's Role ini Realizing The Concept of Economic Jihad". Jurnal Hadhari Edisi Khas 2:2 (Desember 2017).

Hulwati. Teori dan Praktiknya dalam Perdagangan Obligasi Syari'ah di
Pasar Modal Indonesia dan Malaysia. Jakarta: Ciputat Press Group, 2009.

Ibnu Quddamah. Al-Mughni, Cet. I. Beirut: Dar al-Fikr, 1985.

Iqbal, Zamir dan Abbas Mirakhor (ed). Economic Development and Islamic Finance. Washington DC: The World Bank, 2013.

Khisan, Zariatul. "Analisis kinerja perbankan syariah ditinjau dari profitabilitas dan maqasid syariah tahun 2010-2013)". Tesis, Universitas Islam Negeri Malik Ibrahim Malang, 2015.

Lloyd, Bruce. The Role of Capital Market in Developing Countrie. Spring: The Moorgate and Wall Street, 1976.

Maftukhatusolikhah. "Mempertimbangkan Tingkat Maqasid Asy-Syari'ah dalam Penentuan Anggaran Belanja Pemerintah". Jurnal I-Finance 1:1 (Juli 2015).

Nawawi, Ismail. Fiqih Muamalah; Klasik dan Kontemporer. Bogor: Penerbit Ghalia Indonesia, 2012.

Rahmat, Jalaludin. Metodologi Hukum. Jakarta: Fajar Agung, 1997.

Sahroni, Oni dan Adiwarman A. Karim. Maqasid Bisnis dan Keuangan Islam: Sistesis Fiqh dan Ekonomi. Jakarta: Rajawali Press, 2015.

Sugiyono. Metode Penelitian Kuantitatif, Kualitatif Dan $R \& D$. Bandung: Alfabeta, 2013.

Suharso, Yudi Suharso, "8 Manfaat Sukuk Negara", dalam http://akucintakeuangansyariah.com. Diakses pada tanggal 8 Maret 2017.

Sukanto, Suerjono dan Sri Mamudji. Penelitian Hukum Normatif Suatu Tinjauan Singkat, Cet. 11. Jakarta: PT. Raja Grafindo Persada, 2009.

Suma, Muhammad Amin. Menggali Akar Mengurai Serat Ekonomi dan Keuangan Islam. Jakarta: Kholam Publishing, 2008.

Trisnawati, Desi. "Sukuk sebagai Alternatif Investasi Syari'ah di Indonesia". 
Jurnal Kajian Hukum dan Sosial JUSTICIA ISLAMICA 8:1 (Juni 2011).

UU No. 19 Tahun 2008 tentang Surat Berharga Syariah Negara (SBSN).

Zin, Mohamad Zaid Moh., et al. "The Effectiveness of Sukuk in Islamic Finance Market", Australian Journal of Legal, Ethical and Regulatory Issues 12:5 (Oktober 2011). 